Submission ID: 43817

\title{
Development of a Criteria Set for Estimation the Quality of Fluid Seals in the Deposits of the Famennian-Turney Carbonate Sequence in the Orenburg Region on the Basis of Core and Log Data
}

N.N. Chikina* (Tyumen Oil Research Center LLC), Y.I. Nikitin (Tyumen Oil Research Center LLC), E.V. Astafev (Tyumen Oil Research Center LLC), A.P. Vilesov (Tyumen Oil Research Center LLC)

\section{SUMMARY}

The Upper Devonian reefs are one of the main factors of oil accumulations within the Orenburg region. Development of seals in the structures of differential compaction over the Upper-Fransian single basin reefs is not well studied and associated with the main prospects for discovering and involving production of new oil reserves. Identification of true and false carbonate seals by core and log data is based on the techniques and criteria, which lead to targeted search of unexplored oil reserves in the Famennian reservoirs not only in the already discovered Carboniferous deposits, but also in evaluating the prospects for newly acquired licensed areas. 
Разработка комплекса критериев для оценки качества флюидоупоров в отложениях фаменско-турнейской карбонатной толщи Оренбургской области на основе данных керна и ГИС

Н.Н. Чикина*, Ю.И. Никитин, Е.В. Астафьев, А.П. Вилесов (ООО «Тюменский нефтяной научный центр»)

\section{Введение}

Залежи в интервале фаменской толщи приурочены к пяти тектоническим элементам Восточно-Оренбургскому валообразному поднятию (ВОВП), Южно-Татарскому своду (ЮТС), Большекинельскому валу, Бобровско-Покровскому валу, а также к западной части МуханоЕроховского прогиба (МЕП). Все выявленные на сегодняшний день залежи представлены структурами облекания франско-фаменских органогенных построек, которые были выделены по результатам сейсморазведки 3D и бурения (Рис.1).

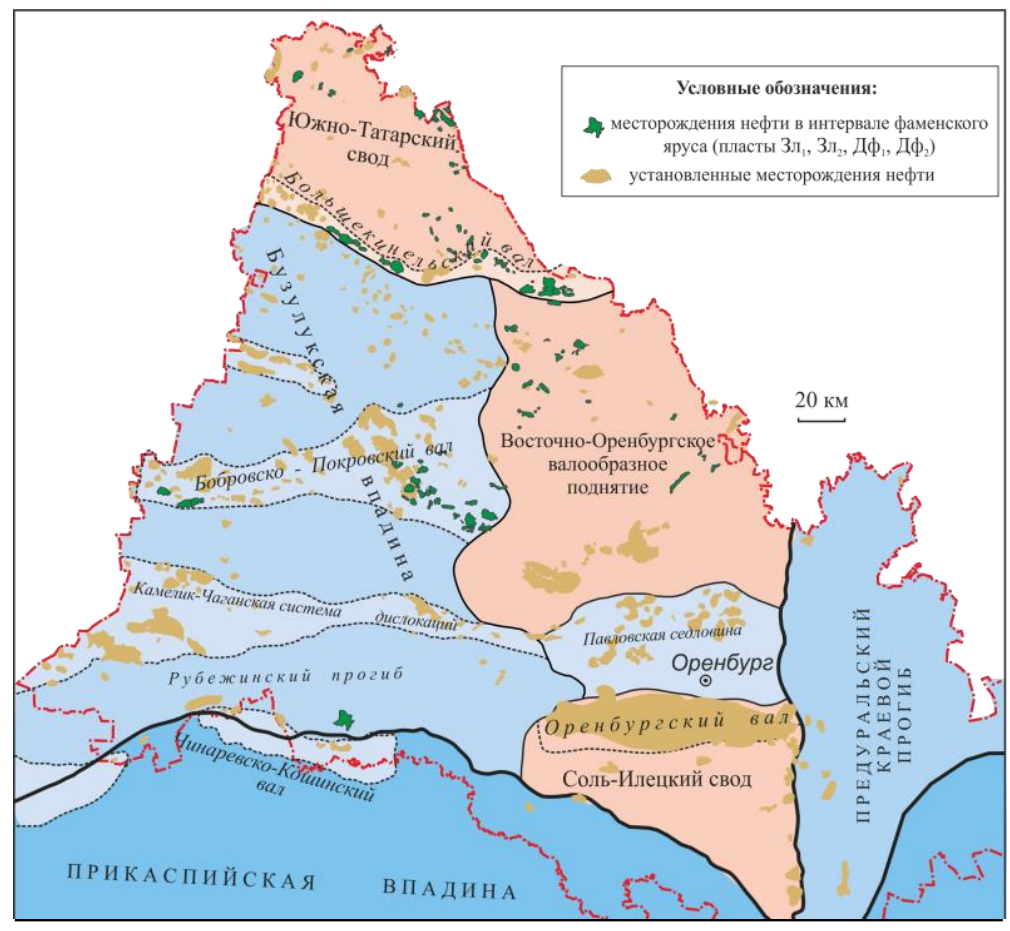

Рисунок 1. Обзорно-тектоническая карта Оренбургской области

В пределах Оренбургской области в фамене открыто 44 месторождения с суммарными начальными извлекаемыми запасами более 30 млн. тонн нефти. Большинство месторождений открыто сравнительно недавно в виду того, что фаменские отложения долгое время не являлись объектом поиска, а основное бурение велось со вскрытием и изучением структурных ловушек карбона. Целенаправленный поиск в зоне неразведанных запасов нефти в фаменских пластах на месторождениях в уже разрабатываемых залежах карбона (добуривание скважин, ЗБС, бурение новых эксплуатационных скважин) открывает большие перспективы для восполнения ресурсной базы. Фаменские продуктивные пласты - Зл1, Зл2, Дф1, Дф2 развиты внутри мелководно-шельфовых карбонатных толщ, которые, как правило, содержат большое количество карбонатных коллекторов. Однако покрышки над пластами-коллекторами, которые также являются карбонатными, развиты не повсеместно и характеризуются большой латеральной изменчивостью. Существует целый ряд скважин, расположенных в сводах структур (доказанных бурением по вышележащим отложениям), в которых не установлена продуктивность. Отсутствие нефтеносности в таких скважинах связано, прежде всего, с низким качеством покрышек. 


\section{Изучение покрышек по данным керна}

При проведении поисково-разведочных работ на нефть и газ в Оренбургской области, в основном, изучаются породы-коллекторы. Остальные породы, в том числе перекрывающие продуктивные горизонты, практически не изучены. В 2016-17 г.г. в Центре исследования керна ООО “ТННЦ” была реализована программа по изучению флюидоупоров фаменских отложений. Из 23 скважин, расположенных в различных тектонических зонах было отобрано 155 образцов и проведен полный комплекс петрофизических исследований, включающий в себя также детальное литологическое и седиментологическое описание пород с характеристикой условий их осадконакопления (Рис.2).



Рисунок 2. Пример комплексного изучения керна в интервале покрышки пласта Дф 2

В ходе работ была подтверждена модель трехслойного строения резервуара, в котором между пластом-коллектором и истинной покрышкой расположен третий элемент - ложная покрышка, а также было установлено, что все покрышки отличаются друг от друга не только по структуре, минералогическому составу, текстурным особенностям, ФЕС, но и условиям их формирования. Флюидоупоры пласта Зль формируют плотные известняки со структурой вакстоун или флаутстоун с прослоями глинистых известняков, сформированные в условиях относительно глубокой сублиторали и сублиторали со спокойной гидродинамикой. Характерной особенностью покрышки пласта Зл2 является наличие пачки глинистых известняков и мергелей глубокой сублиторали. В интервале покрышки пласта Дф1 наблюдается два типа флюидоупоров - извесняки со структурой баундстоун, с фенестрами и включениями сульфатов с редкими прожилками глинистого материала по стилолитам псевдопокрышка, и микрокристаллические известняки со структурой вакстоун с мелкими включениями и прожилками глинистого материала. При достоточной толщине формируют истинную покрышку. Строение флюидоупора пласта Дф2 наиболее сложное. Здесь наблюдается чередование глинистых доломитов лагуны, глинистых известняков вакстоунов сублиторали со спокойной гидродинамикой, плотных литоральных микробиальных байндстоунов.

Для истинных покрышек отмечаются повышенные значения содержания нерастворимого остатка (6.8-28.2\%), пониженные значения пористости (0.6-4.7\%) и проницаемости $(0,01-1,8$ мД) по сравнению с ложными покрышками, отсутствие трещиноватости и нефтепроявлений в керне, высокая плотность. На территории Боголюбовского (пласт Дф1) и Тананыкского (пласт Злㄱ) месторождений выявлены покрышки, представленные чистыми карбонатными известняками, очень плотными, с микритовым цементом, истинность которых подтверждена 
результатами испытаний. Глинистость в таких покрышках минимальна. По данным PCA порода на 96.2\% состоит из кальцита, 2.7\% составляет доломит и лишь $2.1 \%$ иллит. По описанию шлифов зерна занимают $15 \%$ от общей массы образца, $85 \%$-микритовый цемент, а поры составляют $0 \%$.

В результате проведенных исследований был сделан вывод, что для формирования истинных флюидоупоров необходимо два условия: во-первых - присутствие в матрице породы глинистых минералов в виде прожилков, пленок межкристаллического выполнения и вовторых - преобладание в структуре породы микрокристаллического кальцита (микрита). Оба условия реализуются при седиментации в условиях спокойной гидродинамики, чаще всего связанных с повышениями относительного уровня моря или образованием изолированной лагуны. Для прогнозирования сложных покрышек с микритовым цементом необходимо, прежде всего, изучение условий осадконакопления, которые восстанавливаются в процессе построения палеогеографических карт, наличие комплексных исследований керна, расширенного комплекса ГИС.

\section{Изучение качества покрышек по данным ГИС}

Для построения карт качества покрышек на основе сети скважин в условиях крайней ограниченности керна была проведена работа по установлению комплекса критериев, которые позволили бы выделить в разрезе истинные и ложные покрышки по данным каротажа скважин. Количественные критерии определены в процессе анализа покрышек на известных месторождениях с залежами нефти в пластах $3 л_{1}, 3_{2}$, Дф 1 , Дф2 и затем распространены на другие скважины (145 скважин) за их пределами. В качестве опорных было выбрано 50 скважин, в которых имелись испытания, лабораторные исследования керна, газовый каротаж, проведен наиболее полный комплекс ГИС.

Одним из параметров, который использовался в качестве критерия для оценки качества покрышек - глинистость пород. Было установлено, что экранирующие свойства истинных покрышек обеспечиваются, прежде всего, минералогическим составом глинистого материала, смешанно-слойными образованиями ряда гидрослюда-монтмориллонит-хлорит, причем мощность такой глинистой покрышки зачастую не влияет на ее качество. Примером такой глинисто-карбонатной покрышки может служить истинная покрышка пласта Зл2 в пределах восточной части Бобровско-Покровского вала, мощность которой изменяется от 0,8 до 2 м.

На кривых газового каротажа истинным покрышкам отвечают нулевые или минимальные значения газопоказаний, на кривых АКШ - отсутствие проницаемости, определенной по волне Стоунли. По результатам интерпретации материалов ГИС опорных скважин был рассчитан параметр Інгк/Ігк - отношение интенсивности показаний нейтронного гамма-каротажа к интенсивности показаний гамма каротажа, отображающий изменения литологии разреза. На графиках зависимости между параметром Інгк/Ігк и газопоказаниями (Рис.3А), параметром Інгк/Ггк и коэффициентом глинистости (Рис.3Б), построенных с учетом результатов испытаний пластов, были выделены граничные критерии, характеризующие качество покрышки. Для истинной карбонатной покрышки: Інгк/Ігк<3.8, Кгл $>4 \%$, газопоказания $<0.4$.

Еще один из параметров, который может использоваться для оценки качества покрышек это псевдохрупкость, который отражает способность породы растрескиваться под действием приложенного напряжения и удерживать образовавшиеся трещины в открытом состоянии. По скважинам, в которых проведена запись АКШ были рассчитаны модуль Юнга, коэффициент Пуассона и псевдохрупкость (Рис.3В). По графику зависимости псевдохрупкости пород от параметра Інгк/Ігк (Рис.3Г), определено граничное значение псевдохрупкости равное примерно $49 \%$, соответствующее ранее принятому с учетом результатов испытаний граничному параметру Інгк/Ггк=3,8. Для того чтобы рассчитать псевдохрупкость в других скважинах, где не проводился расширенный комплекс ГИС, по этим же скважинам с АКШ было построено сопоставление параметра псевдохрупкости от интервального времени пробега продольной волны и получено уравнение регрессии. Было отмечено, что породы покрышек, обогащенные 
карбонатным материалом, являются более хрупкими, чем пластичные породы покрышек с высоким содержанием глинистого материала. Чаще всего ложные покрышки характеризовались высоким значением псевдохрупкости, они склонны к трещинообразованию и как следствие - флюидопроводимости.

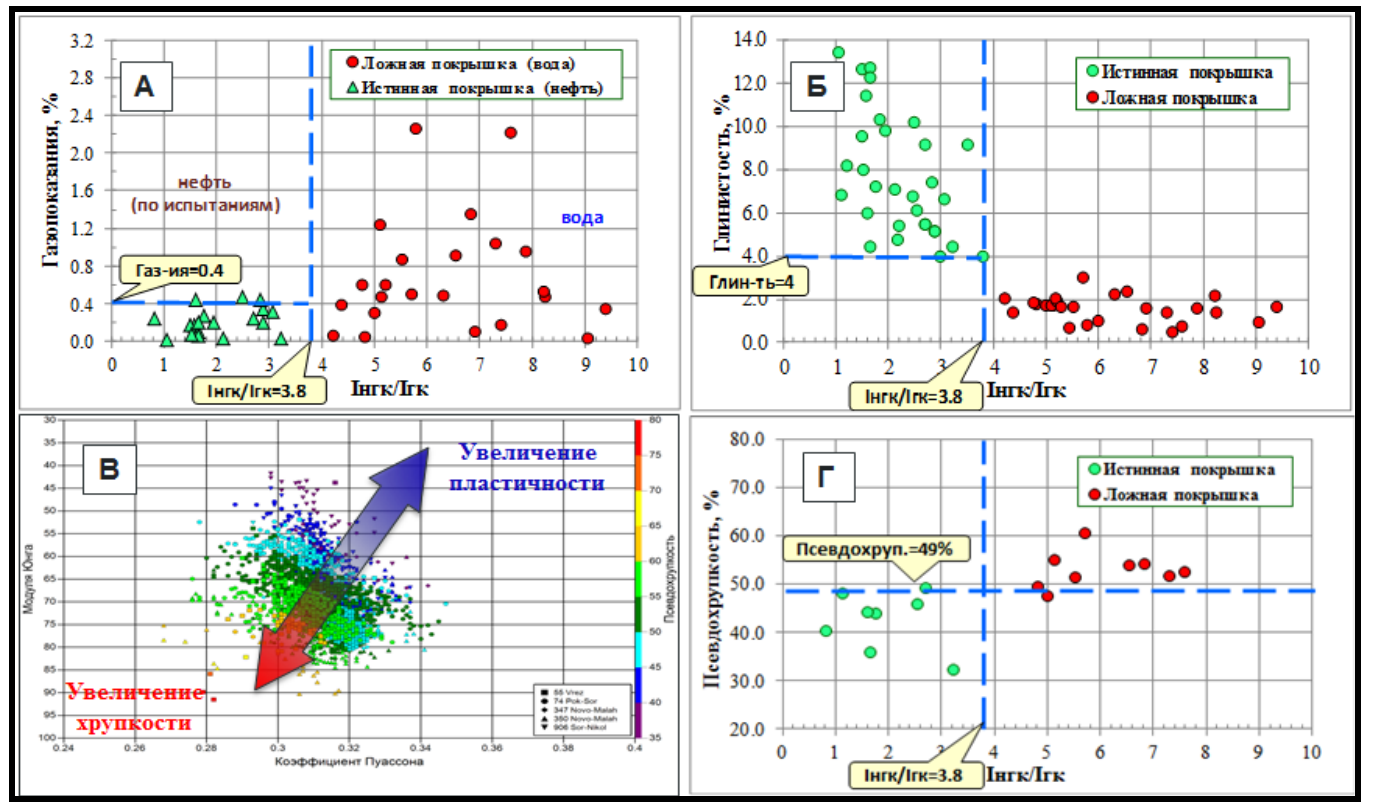

Рисунок 3. Сопоставление параметров ГИС для определения граничных критериев оценки качества флюидоупоров с учетом данных испытаний скважин ( А- Інгк/Ігк от газопоказаний, Б - Інгк/Ігк - Кгл, В- коэффициент Пуассона-модуль Юнга, Г - Інгк/Ігк от псевдохрупкости)

Для анализа качества покрышек было проведено сопоставление дебитов нефти и мощности истинных покрышек для платов ЗЛ, З Зл2, Дф1, Дф 2 по скважинам восточной части БобровскоПокровского вала. Согласно статистике глубокого бурения и испытаний для карбонатных пластов Зл и З Зл2 мощность покрышки более 1.8-1.1 метров соответственно, а для пластов Дф1 и Дф2 более 4 метров достаточна для того, чтобы удерживать залежи УВ. При мощности истинной покрышки менее этих величин необходимо проводить исследования по анализу поровых и капиллярных давлений на границе коллектора и покрышки с привлечением керновых данных механических и прочностных характеристик покрышек для того, чтобы определить при какой минимальной мощности покрышка способна удерживать залежи УВ.

\section{Заключение}

По результатам проведенных исследований свойств покрышек фаменских пластов были построены карты качества покрышек. Территория исследования разделена на участки от минимальной до высокой степени риска наличия покрышки. Применение выработанных критериев для оценки качества фаменских карбонатных покрышек Оренбургской области, еще на начальном этапе поисково-разведочных работ позволило сделать прогноз нефтегазоносности подготовленных объектов, дать количественную величину риска заложения скважин и существенно повысить эффективность геологоразведочных работ.

\section{Литература}

1. Прогноз нефтегазоносности локальных объектов на основе выявления ловушек в трехчленном резервуаре (методические указания) - М.: ВНИГНИ, 1986, - 68 с.

2. Клещев А.А., Строганов В.П. Типы ловушек в природных резервуарах и особенности методики поисков и разведки в них углеводородов. - Нефтегазовая геология и геофизика, М., ВНИИОЭНГ, 1983, вып. 16 (57)

3. Методическое руководство. Выделение, картирование и прогноз нефтегазоносности ловушек в трехчленном резервуаре, ВНИГНИ, М., 2002 г. 


\section{EAGE}

\section{References}

1. Forecast of oil and gas potential of local objects on the basis of detection of traps in a threemember reservoir (methodological guidelines) - M .: VNIGNI, 1986, - $68 \mathrm{c}$.

2. Kleschev AA, Stroganov V.P. Types of traps in natural reservoirs and features of the technique of prospecting and exploration of hydrocarbons in them. - Oil and gas geology and geophysics, Moscow, VNIIOENG, 1983, no. 16 (57)

3. Methodical guidance. Allocating, mapping and forecasting of oil and gas potential of traps in a three-member reservoir, VNIGNI, M., 2002. 